\title{
Incorporating the City Into an Urban Campus's Orientation Program
}

\author{
David W. Benz
}

The notion that the collegiate environment has an impact on freshmen has long been accepted as fact. This impact will vary depending on the nature of the interaction between the student and the environment. Most of the material written on this topic has examined and compared college campuses from perspectives such as public or private, large or small, and two year or four year institutions (Banning, 1989). However, one seldom finds studies addressing the unique needs of freshmen entering institutions located in major metropolitan areas, regardless of size or affiliation. Many student affairs professionals working at institutions located in urban areas will agree that it is difficult to determine where their campuses end and the city begins. This being the case, the collegiate environment is not easily defined; the campus and the city form a seamless entity. Thus, orientation programs must be designed to incorporate the city.

The Maryland Institute, College of Art (MICA) has developed its new student orientation program around this idea. MICA is located in an historic urban neighborhood in Baltimore's cultural corridor. Because of its location, extra effort must be made to ensure that new students are aware of the resources available in the city, are able to access those resources safely, and begin to see themselves as members of their new community. Following are three initiatives taken by MICA to ensure that the orientation program not only addresses the campus environment but also includes the surrounding city.

\section{Personal Safety}

It is imperative that new students become aware of personal safety issues in an urban environment. One of the mandatory orientation sessions is facilitated by the Office of Community Safety and is aptly titled "Life and Security in the City." All aspects of personal safety are addressed, including walking in pairs or groups rather than alone, using the campus shuttle service whenever possible, using public transportation, accessing automatic teller machines, and interacting with a socioeconomically diverse population. As safety education may be alarming, the Community Safety staff has developed methods of delivering the necessary information in a humorous, nonthreatening way. Presentation methods include multimedia and student panels. Efforts are made to ensure that the tone, word choice, and "feel" of the presentations do not create an exaggerated sense of danger among new students. Returning students provide

David W. Benz is Director of Student Activities at Maryland Institute, College of Art. dbenz@mica.edu 
input and assistance in creating and preparing this presentation so that it holds students' attention while addressing all important points.

\section{Printed Materials}

New students at MICA, like most new students, receive large amounts of printed material both before arriving on campus and at orientation. These materials include information about the city of Baltimore. A section of the student handbook is devoted to city resources such as places of worship, cultural institutions, art supply stores and other businesses, and recreation opportunities of interest to college students. The handbook provides directions, suggestions on modes of transportation and, where applicable, cost information. New students also receive a "cartoony and cool" publication written and illustrated by an alumna, providing insights into local attractions that are somewhat unusual or unique. Also included are directions on how to reach these places without the use of a car. The talents of returning students, who are the best resources for knowing what the city offers, also are used to create attractive maps and guides. These items are functional pieces of art which give new students a place to start as they explore their new home.

\section{Tours of the City}

Throughout MICA's new student orientation program, students embark on tours of various sections of Baltimore led by orientation leaders. The first of these tours is conducted using public transportation exclusively. Through the help of the Baltimore Collegetown Network, a consortium of local colleges and universities, day passes for new students are obtained from the Maryland Transportation Authority. Orientation leaders then take groups of new students to one of four interesting neighborhoods within the city. These tours provide students with a glimpse of what Baltimore offers as well as the opportunity to learn how to use public transportation. Another tour is designed to show new students some of the larger museums and art galleries in the city. Orientation leaders receive specialized training to make the tours interactive, informative, and fun.

Recently, MICA had a unique opportunity to measure its success with the tour portion of the program. The Baltimore Collegetown Network conducted a study at 12 colleges and universities in the metropolitan area, looking at public transportation use and the needs of college students. The study found that more than $60 \%$ of MICA students regularly use public transportation. This was the highest percentage among the institutions surveyed (KFH Group Inc., 1999).

\section{Summary}

The collegiate environment has a substantial impact on new students. For institutions in urban areas, the collegiate environment does not end with the campus boundary; the entire city must be considered when planning orientation programs. The Maryland Institute, College of Art accomplishes this by providing new students safety 
presentations, special printed materials, and tours of the city. Institutions within large cities must recognize that their students are not only a part of their campus community but also members of the city's community. With this in mind, it is natural that the city be included in new student orientation programs.

\section{References}

Banning, J.H. (1989). Impact of college environments on freshman students. In M.L. Upcraft \& J.N. Gardner, (Eds.), The freshman year experience (pp. 53-62). San Francisco, Jossey-Bass.

KFH Group, Inc. (1999, March). Technical memorandum \#1: Analysis of transit needs. Bethesda, MD: Author. 